\title{
Financial Specialists
}

National Cancer Institute

\section{Source}

National Cancer Institute. Financial Specialists. NCI Thesaurus. Code C122452.

Workers who meet with customers to help them determine their short-term and longterm financial goals and provide insurance, investment services, certificates of deposits and other financial instruments. They also contact prospective customers, evaluate costs and revenue, make financial presentations and review business trends. 